\title{
Correction of self-destructive behavior of adolescents by means of art therapy
}

\author{
Marina Lukyanenko*, Oksana Isahakyan \\ Kuban State University, 353560 Slavyansk-on-Kuban, Russian Federation
}

\begin{abstract}
In modern society, self-destructive behavior continues to spread among adolescents. This is manifested in the use of alcohol, tobacco smoking, drug addiction, victimization and extreme behavior. The effective implementation of prevention and correction of self-destruction is an urgent problem for personality psychology, educational psychology, developmental psychology and other industries. The article proposes a new scientific approach to overcoming the self-destructive behavior of adolescents. Self-destructive behavior is one of the compensatory defense mechanisms of adaptation and stabilization of the personality, the ability to adapt to adverse conditions. A teenager with an unformed or critical thinking disorder, acting under the influence of fear, anxiety, hopelessness, shame, guilt, excitement, fatigue or a strong affective state of anger and anger, does not think about the consequences of his actions. The formation and implementation of self-destructive behavior serves as a means for the adolescent to maintain a satisfying "Self-concept" - avoiding feelings, from realizing one's inadequacy with one's own idealized ideas, and feeling helpless.
\end{abstract}

\section{Introduction}

The formation and development of the personality of modern adolescents takes place in a rather unpredictable world. Among the younger generation, propaganda of mass pop culture is carried out, which, according to experts, leads to a halt in the development of higher mental functions and the degradation of the personality as a whole [1].

Every day we can observe the dangerous phenomena occurring in society and not attach importance to them. At the same time, there must be an understanding that degradation, affecting the emotional and spiritual sphere of people, leads to a spiritual and cultural crisis, provokes a crisis of relations. All this complicates the formation and development of personality.

Currently, the destructive behavior of adolescents is one of the most acute problems of modern society. With a high speed, the number of teenagers skipping school, failing to

\footnotetext{
*Corresponding author: lukyanenko m@inbox.ru
} 
study, having Internet addiction, drinking alcohol, tobacco and psychotropic drugs is increasing.

The destructive behavior of modern adolescents in the form of self-destructive is the subject of many sciences (philosophy, psychology, medicine, sociology, jurisprudence) [2].

Prevention and correction of self-destructive behavior of adolescents requires an effective solution by all available means, including art therapy methods.

The purpose of this article is to analyze the possibilities of correcting the selfdestructive behavior of adolescents using art therapy.

\section{Statement of the main material}

Self-destructive behavior is a behavior aimed not at achieving biological, psychological and social well-being, development and growth of a person, but at self-destruction and premature death $[3,4]$.

Among modern adolescents, one of the more common manifestations of self-destruction is: addictive and addictive behavior (alcohol, smoking, a test of psychotropic drugs, Internet addiction); risky behavior (victim behavior, passion for extreme leisure, casual sex); socially passive behavior (fleeing from home, avoiding studies, vagrancy and begging); self-aggressive behavior (self-harm, suicide attempts) $[3,4,5]$.

In psychology, the problem of self-destructive behavior is described in scientific works: O. O. Andronikova, I. V. Berno-Bellekura, B. S. Bratusya, T. N. Gorobets, T. A. Donskikh, C. P. Korolenko, A. E. Lichko [2; 6].

The theory of self-aggression was considered: A. G. Ambrumova, E. M. Vrono, G. Ya. Pilyagin, N. A. Ratinova, A. A. Rean, E. G. Trainina, Z. Freud, A. Freud, K. Horney $[3,4,6]$.

The phenomenon of psychological defense is clearly expressed in scientific research: $F$. E. Vasilyuk, A. Freud, Z. Freud. The concepts of coping with extreme situations were developed by A. A. Bodaleva, A. I. Eremeeva, E. I. Kirshbaum, R. Lazarus, A. V. Libina [6].

Scientists have proposed a large number of diverse methods of correction and prevention of self-destructive behavior. Among them, one can distinguish art therapy, which does not have the ability to change trauma of the past or heal deep psychological and emotional disorders, but it can reduce the fear of loneliness, mobilize and develop internal resources, opening the way to emotional rehabilitation [7].

The effectiveness of art therapy was confirmed by a wide range of music therapy works by L. S. Brusilovsky, I. M. Grinev, V. I. Petrushkin; on vocal therapy: S.V. Shushardzhan; for isotherapy: M. E. Burno, A. I. Zakharov, R. B. Khaikin; in bibliotherapy: A. M. Miller, V. V. Murashevsky, Yu. B. Nekrasova, E. Yu. Rau; for imagotherapy: I. E. Volpert, N. S. Govorov [8].

The main causes of destructive human behavior are such as: lack of self-realization in creativity, a feeling of loneliness, isolation, insecurity in oneself and one's abilities, experiencing one's own depression, boredom. The outstanding Austrian physiologist K. Lorenz was engaged in the study of aggressive behavior as a biologically innate principle in man. In modern society, such scientists as T. A. Donskikh and Ts. P. Korolenko paid special attention to self-destructive behavior. This behavior has received the term "selfdestructive". It is noted that such a phenomenon is directly opposite to self-realization and self-development of a person [2, 9, 10].

An analysis of the literature showed that the problem of self-destructive behavior is very relevant in modern society. Self-destructive behavior is a complex and dangerous form of behavior that is widespread at present $[2,9,10]$. 
Adolescence is one of the most important and responsible life periods. It is often called critical, but this is not without reason. Specialists working in schools are largely responsible for the kind of people their students will grow up. But the formation of the adolescent's personality is also influenced by other important factors, for example, the occurrence of difficulties in communicating with classmates and peers, disadaptation to the class can become one of the reasons for the emergence of self-destructive behavior [11].

In adolescents, any form of manifestation of self-destructive behavior is compounded by the inability to understand their feelings, feelings, anxieties. But it is at this age that a person acquires character traits and personality characteristics that further determine his success [12].

Art therapy is one of the oldest and most direct forms of psychological correction that society uses without the help of other people to relieve accumulated emotional tension, pull itself together, and concentrate. In 1938, the British painter Adrian Hill introduced the term art therapy when describing his activities with tuberculosis patients in rest homes. This combination of words was applied to absolutely all types of art training conducted in hospitals, clinics, and psychological health centers [8].

Art therapy involves a complex of psychocorrectional techniques that have characteristic features and differences, which belong both to a specific type of creativity, and focus, the technology of psychocorrectional therapeutic use. Spontaneous visual activity expresses the hidden content of mental life. Art therapeutic techniques can be carried out both individually and in a group. For example, individual art therapy can be used in psychiatry for people to whom verbal psychotherapy cannot be applied, clients with shallow mental disorders of a neurotic nature, or for children and adults with problems of verbalization (autism, stuttering, low contact), and post-traumatic disorders [13].

Creativity therapy may become a new page in the theory and practice of social work with its wide clientele.

Research methods. To achieve the goal of the study, which was to develop, implement and verify the effectiveness of the program for correcting self-destructive behavior of adolescents using art therapy, we conducted a study in the MBEI secondary school in the city of Slavyansk-on-Kuban. The study involved students of 8 "A" and 8 "B" classes, $14-15$ years old, in the amount of 40 people. Research methods: "Tendency to deviant behavior" methodology E. V. Leus ("TDB”), A. G Soloviev, "13 dependencies" methodology, G. V. Lozova, Bass-Darki's "Indicators and forms of aggression" methodology [14, 15].

The main results of the study. At the ascertaining stage of the experiment, a tendency to deviant behavior was revealed in 11 adolescents using the TDB (tendency to deviant behavior) method E. V. Leus, NFU im. M.V. Lomonosov; A. G. Soloviev, SSMU, Arkhangelsk. The compiled sample of adolescents conducted a methodology for identifying various types of dependencies (addiction) "13 types of dependencies" G. V. Lozova, the method "Diagnosis of indicators and forms of aggression" A. Bass, A. Darki.

Analyzing the results of the "TDB" methodology, it can be noted that on the scale of socially determined behavior (SDB), 3 people with a high level and 1 with a low level were identified. On a scale of delinquent (unlawful) behavior (DetB), 2 students showed a high level. Dependent behavior (DepB) was detected in 3 adolescents. A high level of aggressive behavior $(\mathrm{AB})$ was detected in 4 students and an average indicator with a tendency to high was detected in one student. Self-destructive (SD) behavior was not detected among adolescents.

According to the results of the "TDB" methodology, E. V. Leus and A. G. Solovyov, we can notice that some of the highest indicators are identified in the scale of socially determined behavior (SDB) - 16\%. This fact indicates that these students have adapted behavior to a significant group for them, possibly having both a deviant and a positive orientation. Dependence on other people or communication. 
Delinquent or unlawful behavior (DelB) was detected in 2 teenagers - 10\%. Such students are characterized by petty hooliganism, obscene language, an offensive manner of treatment. In relation to the educational process, safety violations, absenteeism, the appearance in the school in a state of alcoholic, narcotic or toxic intoxication may occur.

A high indicator of dependent behavior (DepB) was found in $16 \%$ of the class -3 students and a situational predisposition to it in $10 \%$ of the class, which is 2 students. When characterizing the scale of addictive behavior, you need to take into account the variety of types of addictions such as: chemical, food addiction, gambling, Internet addiction, sports addiction and others. We will find out exactly which dependencies are characteristic of the emerging adolescents using our following methodology.

A high rate of aggressive behavior (AB) in 8 " $\mathrm{A}$ " class was found in 4 people, which amounted to $21 \%$ of the total number of children in the class. The average level of addictive behavior was revealed in 5 teenagers, which is $26 \%$ of the total class amount, among them student Tatyana P. who is at the junction between the middle and high level of dependence, stands out automatically, being at risk.

Self-destructive behavior (SB) was also not detected among adolescents, $10 \%$ of students have moderate severity, but these indicators are not critical, as the number of points is closer to a low level. Aggression of a teenager can be verbal and physical, aimed at surrounding people, hostility, negativity, audacity and revenge.

According to the results of the "SDP" methodology, in the 8th "B" class, 9.5\% of students with a high level and $9.5 \%$ with a low level were identified in the scale of socially determined behavior (SDB). Delinquent (unlawful) behavior (DelB) was manifested in $9.5 \%$ of adolescents in grade 8 "B". Formed dependent behavior (DepB) was detected in $5 \%$ of the entire class. High level of aggressive behavior (AB) $-9.5 \%$ of adolescents. Self-destructive behavior (SelfDB) among adolescents in grade 8 "B" was not identified.

Thus, thanks to the "SDP" methodology of E.V. Leus and A. G. Soloviev, we identified 11 adolescents with a high degree of severity of maladaptation with various types of deviant behavior. Deviant behavior in adolescence can be expressed by running away from home and ending with robberies and suicide. The adolescents whom we identified are in the zone of social risk in order to exclude this fact; in the future, correction work will be carried out with the help of the developed correction program.

To solve the goals and objectives, we have developed and implemented a program for correcting self-destructive behavior using art therapy, aimed at the formation and development of skills to overcome difficulties, cope with destructive emotions and conditions, communicative competence of adolescents, self-analysis skills, the ability to interact with other people and resolve conflicts.

When comparing the data obtained before and after the implementation of the correction program, it became noticeable that on the "Internet" dependency scale, indicators were reduced from a high level to an average of 3 people, which is $27 \%$ of the total number of the study group; indicators on the scale of the Internet dependence changed from average to low 2 people, which is $18 \%$ of the study group.

As mentioned earlier on the "Love" scale, the first stages of the study did not reveal a high rate of dependence, only an average level. During re-diagnosis, one student lowered her performance from an average level of dependence to a low.

According to the "TV" dependence scale, when re-diagnosing, 2 people changed their indicators from a high level to an average, which amounted to $18 \%$ of the studied group of teenagers, and one student changed her indicators from an average to a low level of addictive behavior.

On a scale of "General propensity", two students changed the number of points, which amounted to $18 \%$ of the study group, thereby interpreting the results revealed their transition from an average level of dependence to low. 
The classes had a positive effect on girls from the study group, unfortunately, correctional work did not significantly affect the male half.

Also in the study group, repeated diagnostics were carried out according to the previously used Bass-Darki method "Diagnosis of indicators and forms of aggression" after the implementation of the correction program.

When reprocessing the results using the Bass-Darki methodology "Diagnostics of indicators and forms of aggression", it turned out that after the implementation of corrective work, two students changed their answers on the "Hostility" scale to the provided statements, thereby entering the framework of average indicators on this scale. With the help of corrective work, we also managed to reduce high-level indicators on the scale "Aggressiveness" in 3 adolescents, thanks to which, the guys showed results by a repeated technique, thereby entering the framework of average indicators on this scale. On the scale of "Guilt", unfortunately, there was no positive trend on the part of adolescents.

\section{The discussion of the results}

Based on the results of the research, we can talk about the effectiveness of the developed correction program.

The results of our study allowed us to formulate the following conclusions.

1. Self-destructive behavior under adverse conditions can be included in the system of personality self-regulation as a factor in maintaining the integrity of a person's personality, maintaining a positive self-relationship, avoiding the experience of frustration.

2. A comprehensive system of measures for the prevention of self-destructive behavior, including diagnostic, educational, correctional and developmental work in a general educational institution, can be an effective tool for its regular implementation.

3. The implementation of the proposed program for the correction of self-destructive behavior by means of art therapy helps to reduce the risk of self-destructive manifestations of adolescents. Promotes the development of their subjective position and increase their importance. Increases the ability of adolescents to use coping strategies in acute and prolonged adverse situations.

The results presented in the article may be of interest for further study of the problem of prevention of self-destructive behavior in adolescence in aspects of the study of its general mechanisms and the search for the most universal and effective means and methods of correction.

\section{Conclusion}

The preventive and corrective effect on leveling the teenager's self-destructive behavior can be implemented in educational institutions with the maximum coverage of school specialists: psychologist, teachers, social worker, head teacher for educational work and other employees of the organization. Early detection of signs of self-destructive behavior in a teenager will allow for timely corrective work. In order to effectively prevent and correct auto-destructive behavior of adolescents, art therapy can be used.

\section{References}

1. T.P. Avdulova, Agressivnost'v podrostkovom vozraste (2019)

2. Yu.V. Obukhova, Sovremennaya prakticheskaya psihologiya $v$ obespechenii resursov samorealizacii lichnosti (2016)

3. E.V. Zmanovskaya, Deviantologiya (Psihologiya otklonyayushchegosya 
povedeniya) (2008)

4. Yu.A. Kleiberg, Psihologiya deviantnogo povedeniya (2017)

5. D.I. Shustov, Autoagressiya, suicid i alkogolizm (2004)

6. P. S. Samygin, Profilaktika deviantnogo povedeniya molodezhi (2019)

7. M.N. Filippov, Organizaciya social'no-pedagogicheskoj raboty po profilaktike $i$ korrekcii destruktivnogo povedeniya detej i podrostkov (2015)

8. A.I. Kopytin Metody art-terapii v preodolenii posledstvij travmaticheskogo stressa (2014)

9. I.V. Abakumova, M.V. Godunov, A.L. Enin, Z.Sh. Generdukaeva, Strategii smysloobrazovaniya: sovremennye predstavleniya $v$ rabotakh otechestvennykh issledovatelei (2016)

10. A.G. Asmolov, Optika prosveshcheniya: sotsiokul'turnye perspektivy (2012)

11. I.V. Abakumova, P.N. Ermakov, V.T. Fomenko, Novodidaktika. Kniga 1. Metodologiia i tekhnologii obucheniia: $\mathrm{v}$ poiskakh razvivaiushchego resursa (2013)

12. I.V. Abakumova, Smysloobrazovanie v uchebnom protsesse (2003)

13. I.V. Abakumova, P. N. Ermakov, V.T. Fomenko, Novodidaktika. Kniga 2. Obrazovatel'nye tekhnologii: novye rakursy (2013)

14. V.A. Beizer Praktikum po deviantologii (2014)

15. I.V. Vasilyeva Psihodiagnostika (2013) 